\title{
IMPLEMENTASI PEMERINTAH DAERAH DALAM PENGEMBANGAN MODEL PELAYANAN PUBLIK BERBASIS SISTEM INFORMASI DESA PADA PEMERINTAHAN DESA DI KABUPATEN JEPARA PERSPEKTIF ISLAM TERAPAN
}

\author{
Aristoni ${ }^{1}$, Any Ismayawati ${ }^{2}$ \\ Fakultas Syariah IAIN Kudus ${ }^{12}$ \\ Email :aristoni@iainkudus.ac.id1 ,Email:any.ismayawati@yahoo.com²
}

\begin{abstract}
The application of the village information system is essentially an inseparable part of the form of local government responsibility in the implementation of public service development at the village level by utilizing Information and Communication Technology (ICT) to meet the needs of the community and all stakeholders, so that it is not excessive development of public services here is understood to be strategic point to build good governance practices. This article aims to determine the implementation of the Jepara Regency Regional Government in developing a model of village information system-based public services seen from the perspective of Applied Islam, and to find out the constraints and efforts that can be made by the Jepara Regency Government in implementing the development of a village information system-based public service in the village government. This type of research is included in the category of field research using the juridical-sociological approach. The reason for choosing to use this approach is because the data needed is in the form of information that does not need to be quantified. The distribution of information was obtained from interviews with the informants.

The results show that the implementation of the development of public services based on the village information system carried out by the Jepara regency government through Dinsospermades in Jepara Regency is in line with the concept of Applied Islam, meaning that the Regional Government of Jepara Regency as an institution has fulfilled its obligations by implementing Article 86 of Law Number 6 of 2014 about the village in order to realize the benefit of the community related to easy access to information and village data services. The meeting point between the concept of Applied Islam and the Village Law is equally aimed at the benefit or welfare of the community. The forms of implementation include the socialization of village information systems, providing training and technical guidance to village operators, conducting monitoring and evaluation. One obstacle faced by one of them is the weak human resources of village operators so that it has implications for the ineffectiveness in managing village information systems at the village level.
\end{abstract}

Keywords: Local Government and Village Government, Public Services, Village Information Systems 


\begin{abstract}
Abstrak
Penerapan sistem informasi desa hakikatnya merupakan bagian yang tidak terpisahkan dari bentuk tanggung jawab pemerintah daerah dalam pelaksanaan pengembangan pelayanan publik ditingkat desa dengan memanfaatkan Teknologi Informasi dan Komunikasi (TIK) guna memenuhi kebutuhan masyarakat dan semua pemangku kepentingan, sehingga tidak berlebihan pengembangan pelayanan publik di sini dipahami menjadi titik strategis untuk membangun praktik pemerintahan yang baik. Artikel ini bertujuan untuk mengetahui pelaksanaan Pemerintah Daerah Kabupaten Jepara dalam pengembangan model pelayanan publik berbasis sistem informasi desa dilihat dari perspektif Islam Terapan, dan untuk mengetahui kendala dan upaya yang dapat dilakukan Pemerintah Daerah Kabupaten Jepara dalam pelaksanaan pengembangan pelayanan publik berbasis sistem informasi desa pada pemerintahan desa. Jenis penelitian ini termasuk dalam kategori penelitian lapangan dengan menggunakan metode pendekatan yuridis-sosiologis. Alasan memilih menggunakan metode pendekatan ini karena data-data yang dibutuhkan berupa sebaran informasi yang tidak perlu dikuantifikasikan. Sebaran informasi tersebut diperolah dari hasil wawancara dengan para informan.

Hasil penelitian menujukkan bahwa pelaksanaan pengembangan pelayanan publik berbasisi sistem informasi desa yang dilakukan Pemerintah Daerah Kabupaten Jepara melalui Dinsospermades Kabupaten Jepara sudah sejalan dengan konsep Islam Terapan, artinya Pemeritah Daerah Kabupaten Jepara sebagai institusi telah melaksanakan kewajibannya dengan mengamalkan Pasal 86 Undang-Undang Nomor 6 Tahun 2014 tentang Desa demi mewujudkan kemaslahatan masyarakat terkait kemudahan akses pelayanan informasi dan data desa. Titik temu antara konsep Islam Terapan dengan Undang-Undang tetang Desa adalah sama-sama bertujuan untuk kemaslahatan atau kesejahteraan masyarakat. Adapun bentuk pelaksanaanya meliputi sosialisasi sistem informasi desa, memberikan pelatihan dan bimbingan teknis kepada operator desa, melakukan monitoring dan evaluasi. Kendala yang dihadapi salah satunya adalah lemahnya sumber daya manusia operator desa sehingga berimplikasi pada ketidakefektifan dalam pengelolaan sistem informasi desa ditingkat desa.
\end{abstract}

Kata Kunci : Pemerintah Daerah dan Pemerintahan Desa, Pelayanan Publik, Sistem Informasi Desa

\title{
PENDAHULUAN
}

Salah satu agenda reformasi adalah tuntutan pemberian otonomi yang luas kepada daerah kabupaten/kota. Tuntutan seperti ini merupakan hal yang wajar dan setidaknya terdapat beberapa alasan salah satunya adalah intervensi Pemerintah Pusat yang begitu besar dimasa lalu telah menimbulkan masalah rendahnya kapabilitas dan efektivitas pemerintah daerah dalam mendorong proses pembangunan dan kehidupan demokrasi di daerah (Mardiasmo, 1999: 4). Akibat dari intervensi Pemerintah Pusat tersebut menyebabkan inisiatif dan prakarsa 
Implementasi Pemerintah Daerah dalam Pengembangan...

daerah cenderung mati sehingga pemerintah daerah sering kali menjadikan pemenuhan peraturan sebagai tujuan, dan bukan sebagai alat untuk meningkatkan pelayanan kepada masyarakat (Mardiasmo dan Halim, 1999: 5).

Tuntutan pemberian otonomi juga dipahami sebagai jawaban untuk memasuki zaman permainan baru (era new game) yang membawa aturan-aturan baru (new rule) pada semua aspek kehidupan manusia dimasa yang akan datang. Di era ini pemerintah akan semakin kehilangan kendali pada banyak persoalan, seperti restrukturisasi pegawai, peningkatan pelayanan, perbaikan administrasi, informasi, dan ide yang mengharuskan pemerintah daerah pada khususnya di sektor publik untuk mempersiapkan diri secara institusional (Mardiasmo, 2002: 4). Salah satunya adalah dengan mengembangkan lembaganya sebagai lembaga yang memiliki birokrasi yang sehat utamanya dalam meningkatkan pelayanan publik yang berbasis pada pelayanan prima (service excellent) kepada masyarakat sesuai standar pelayanan cepat, tepat waktu, akurat, trasnparan, profesional, murah, ramah dan adaptif (Kurniawan, 2016: 17).

Penerapan pelayanan prima yang diberikan oleh pemerintah ini sebagai upaya memberikan kepuasaan bagi masyarakat sebagai penggunan layanan sesuai dengan prinsip-prinsip penyelenggaraan pemerintahan yang baik (good governance). Menurut Ketentuan Umum Pasal 1 Undang-Undang Nomor 25 Tahun 2009 tentang Pelayanan Publik, menyebutkan bahwa pelayanan publik adalah kegiatan atau rangkaian kegiatan dalam rangka pemenuhan kebutuhan pelayanan sesuai dengan peraturan perundang-undangan bagi setiap warga negara dan penduduk atas barang, jasa dan/atau pelayanan administrasi yang disediakan oleh penyelenggara pelayanan publik.

Secara teoretis, terdapat tiga fungsi pelayanan yang harus dijalankan oleh pemerintah yaitu environmental service, development service, dan protective service. Pelayanan oleh pemerintah tersebut dibedakan berdasarkan siapa yang menerima layanan, apakah pihak individu, atau pihak kelompok (Miftah, 1996: 180). Kendati demikian, pelayanan yang diberikan oleh pemerintah diperlukan evaluasi secara berkala dan berkesinambungan agar pemerintah dapat meningkatkan perannya utamanya dalam penyelenggaraan pelayanan informasi dan data. (Kurniawan, 2016: 572).

Di era revolusi industri 4.0 menuju era socety 5.0 sekarang ini, pelayanan publik kembali menjadi perbincangan cukup hangat dikalangan akademisi, pengamat, maupun pemangku kebijakan publik, seiring banyaknya tuntutan kepada pemerintah dan pemerintah daerah sebagai penyedia jasa layanan untuk mampu bekerja secara profesional terlebih lagi terhadap pelayanan informasi dan data yang ditujukan untuk kepentingan masyarakat dan semua pemangku kepentingan. 
Lahirnya Undang-Undang Nomor 6 Tahun 2014 tentang Desa membawa implikasi positif sekaligus sebagai payung hukum bagi pemerintah dan pemerintah daerah kabupaten/kota di Indonesia tak terkecuali Pemerintah Daerah Kabupaten Jepara untuk mengembangkan model pelayanan publik berbasis sistem informasi desa dan pembangunan kawasan perdesaan. Dengan sistem informasi desa yang terintegrasi dengan website desa ini diharapkan dapat memberikan kemudahan bagi masyarakat desa dan semua pemangku kepentingan dalam mengakses kebutuhan data desa, data pembangunan desa, kawasan perdesaan, serta informasi lain yang berkaitan dengan pembangunan desa dan pembangunan kawasan perdesaan secara cepat dan mudah.

Semangat Pemerintah Daerah Kabupaten Jepara melalui Dinsospermades Kabupaten Jepara dalam melaksanakan pengembangan sistem informasi desa tersebut dimaknai sebagai bentuk inovasi terhadap pelayanan publik pada ranah desa, namun sayangnya pelaksanaan program pengembangan pelayanan publik ditingkat desa ini tidak diimbangi dengan keseriusan pemerintah desa dalam mengelola website desa, bahkan ironisnya masih banyak dijumpai website desa yang dimiliki oleh pemerintah desa masih kosong atau tidak dikelola dengan baik, padahal semestinya website desa yang terintegrasi dengan sistem informasi desa tersebut dapat difungsikan sebagai lumbung data bagi Desa. Fakta ini menjadi sangat tidak relevan mengingat pemerintah desa sebagai ujung tombak keberhasilan dalam penyelenggaraan pelayanan informasi dan administrasi pemerintahan di tingkat desa untuk mendukung program pemerintah dan pemerintah daerah.

Dalam perspektif Islam Terapan bahwa keadaan demikian itu tentu tidak dapat dibenarkan mengingat jabatan di pemerintah desa merupakan amanah, maka sudah seharusnya sebagai pemangku kebijakan dalam hal ini kepala desa melaksanakan amanah sebagai wujud menjalankan praktik keberagamaan demi terwujudnya kesejahteraan masyarakatnya dibidang pelayanan. Hakikat hukum Islam adalah hukum agama dimana Islam mengatur seluruh aspek kehidupan manusia tak terkecuali dalam bidang ketatanegaraan (siyasah) yang berhubungan dengan Pelayanan (Nasution, 1996: 98). Dalam paradigma Islam Terapan, agama tidak hanya dipahami sebatas pengetahuan doktrin atau ajaran saja, melainkan bagaimana pengetahuan tentang ajaran agama tersebut diaplikasikan dalam wujud perilaku kongkrit sebagai pribadi orang beriman.

Perilaku kongrit atas pengamalan ajaran agama menurut Muslim A. Kadir (2003) disebut sebagai perilaku keberagamaan (religiusitas) sebagai respon terhadap wahyu yang diungkapkan dalam bentuk pemikiran, perbuatan kehidupan berkelompok. Jika segala sesuatu yang 
Implementasi Pemerintah Daerah dalam Pengembangan...

kita kerjakan sesuai dengan tuntunan Al-Qur'an dan Sunnah, maka akan bernilai ibadah (Kadir, 2003: 105-106).

Dari hasil penelusuran penelitian sebelumnya yang masih ada relevansi dengan judul penelitian ini diantaranya penelitian yang dilakukan oleh Putra Samudra, et al, dengan judul "Sistem Administrasi Pelayanan Pemeritah Desa Berbasis Website Studi Kasus Kantor Balai Desa Kendalkemilagi Kecamatan Karanggeneng Kabupaten Lamongan", di mana kajian penelitian ini menfokuskan tentang bagaimana pembuatan Sistem Aplikasi Administrasi Pelayanan Pemerintah Desa (SAPPDESA) berbasis website dengan menggunakan metode waterfall sebagai langkah dalam menyelesaikan persoalan keadministrasian mulai dari pelayanan surat keluar yang kurang rapi,pembuatan laporan registrasi kependudukan hingga kesulitan dalam rencana APBD (Samudra, et.al., 2017). Kemudian Penelitian yang dilakukan Sri Warjiyati dengan judul "Tinjauan Hukum Islam Terhadap Penerapan Good Governance dalam Pelayanan Publik". Kajian penelitian lebih mengarah tentang bagaimana cara mendayagunakan metode yang ditawarkan dalam ilmu Ushul Fikih untuk merumuskan asas-asas hukum Islam di dalam merespon berbagai persoalan yang terjadi dalam tata kelola pemerintahan (Warjiyati, 2018).

Berdasarkan penelitian sebelumnya di atas, setidaknya dapat dijadikan sebagai basis dalam penelitian ini. Adapun perbedaan mendasar antara penelitian sebelumnya dengan penelitian ini adalah dari aspek tinjuannya. Penelitian ini mengkaji tentang bagaimana implementasi pemerintah daerah dalam pengembangan model pelayanan publik berbasis sistem informasi desa pada pemerintahan desa di Kabupaten Jepara dilihat dari perspektif Islam Terapan, dan bagaimana kendala dan upaya yang dapat dilakukan pemerintah daerah dalam pengembangan pelayanan publik berbasis sistem informasi desa pada pemerintahan desa di Kabupaten Jepara. Hasil penelitian ini nantinya diharapkan dapat berkontribusi bagi semua komponen pemerintah dalam penyelenggaraan pemerintahan baik di tingkat pusat, daerah maupun di tingkat desa terkait penerapan sistem informasi desa dengan memanfaatkan Teknologi Informasi dan Komunikasi (TIK) tepat guna sehingga dapat mempercepat pembangunan desa di segala bidang terutama dalam peningkatan kualitas pelayanan publik.

\section{METODE PENELITIAN}

Penelitian ini merupakan jenis penelitian lapangan (field research) yaitu penelitian yang mengambil data primer dari lapangan, daerah atau lokasi (locus) tertentu (Sugono, 2003: 44). Lokasi yang menjadi obyek penelitian ini diantaranya Kantor Dinas Sosial Pemberdayaan Masyarakat dan Desa (Dinsospermades) Kabupaten Jepara dan Kantor Kepala Desa di Kabupaten Jepara. Metode pendekatan yang digunakan dalam penelitian 
ini adalah pendekatan yuridis sosiologis, yakni mengidentifikasikan dan mengkonsepsikan hukum sebagai institusi sosial riil dan fungsional dalam sistem kehidupan yang mempola (Soemitro, 1982: 17). Alasan penulis memilih menggunakan pendekatan yuridis sosiologis karena data-data yang dibutuhkan berupa sebaran-sebaran informasi yang tidak perlu dikuantifikasikan. Sebaran-sebaran informasi yang dimaksud ialah yang di dapat dari hasil wawancara dengan para informan.

Sumber data yang digunakan berupa data primer dan data sekunder. Data primer diperoleh dari wawancara (inteview) dengan para informan diantaranya Kepala Dinsospermades Kabupaten Jepara, Kasi Penguatan Perencanaan Pembangunan Partisipatif Dinsospermades Kabupaten Jepara, Kepala Desa, dan Perangkat Desa/Operator Desa. Sedangkan data sekunder terdiri dari kepusatakaan berupa buku-buku, artikel, skripsi, tesis, surat kabar, majalah, Peraturan PerundangUndangan dan bahan lainnya yang berhubungan dengan judul penelitian ini. Teknik pengumpulan data berupa pengamatan (observasi), studi kepustakaan, dan wawancara dengan teknik bebas terpimpin. Uji keabsahan data pada penelitian ini menggunakan uji kredibilitas yang terdiri dari perpanjangan pengamatan, meningkatkan ketekunan, dan triangulasi berupa triangulasi sumber, triangulasi cara/teknis, triangulasi waktu, dan member check. Adapun teknik analisis data yang digunakan adalah diskriptif kualitatif yaitu menguraikan data secara bermutu dalam bentuk kalimat yang teratur, runtun, logis dan tidak tumpang tindih sehingga memudahkan pelaksanaan data dan pemahaman hasil analisis (Muhammad, 2004: 127).

\section{PEMBAHASAN}

\section{Konsep Pelayanan Publik dan Sistem Informasi Desa}

Secara sederhana pelayanan dapat dipahami merupakan suatu proses hubungan interaksi antara pemberi layanan (provider) dengan penerima pelayanan (demander) yang dalam ilmu pemerintahan diartikan sebagai hubungan pemerintahan (Moenir, 2008: 27). Sinambela (2014) dalam bukunya berjudul "reformasi pelayanan publik" dikutip Rabby Nazki mengatakan bahwa pelayanan merupakan pemberian layanan untuk keperluan penerima layanan yang memiliki kepentingan pada organisasi sesuai dengan aturan maupun mekanisme yang telah ditetapkan (Nazli, 2019: 89). Dalam konteks ini aspek penting dalam pelayanan adalah kualitas pelayanan yang sering menjadi permasalahan. Menurut Thoha bahwa kualitas pelayanan menjadi dasar penentuan dan perkembangan hubungan interaksi pelayanan dan yang dilayani (Miftah, 1996: 181).

Sementara itu, pelayanan publik didefinisikan sebagai bentuk jasa pelayanan baik dalam bentuk barang publik maupun jasa publik yang 
Implementasi Pemerintah Daerah dalam Pengembangan...

pada prinsipnya menjadi tanggung jawab dan dilaksanakan oleh instansi pemerintah pusat, pemerintah daerah, dan dilingkungan Badan Usaha Milik Negara atau Badan Usaha Milik Daerah dalam rangka upaya pemenuhan kebutuhan masyarakat maupun dalam rangka pelaksanaan ketentuan Perundang-Undangan. Adapun tujuan pelayanan publik hakikatnya adalah untuk memuaskan masyarakat (Apriyansyah, dkk, 2018: 13).

Pasal 1 Undang-Undang Nomor 25 Tahun 2009 tentang Pelayanan Publik, menyatakan bahwa pelayanan publik adalah kegiatan atau rangkaian kegiatan dalam rangka pemenuhan kebutuhan pelayanan sesuai dengan Peraturan Perundang-Undangan bagi setiap warga negara dan penduduk atas barang, jasa, dan/atau pelayanan administratif yang disediakan oleh penyelenggara pelayanan publik. Penyelenggaraan pelayanan publik berdasarkan Undang-Undang ini sekurang-kurangnya meliputi beberapa hal sebagai berikut :

1) Pelaksanaan pelayanan;

2) Pengelolaan pengaduan masyarakat;

3) Pengelolaan informasi;

4) Pengawasan internal;

5) Penyuluhan kepada masyarakat; dan

6) Pelayanan konsultatif.

Berdasarkan beberapa pengertian pelayanan publik di atas, maka dapat disimpulkan bahwa pelayanan publik merupakan pemberian pelayanan atau melayani keperluan orang atau masyarakat dan/atau organisasi lain yang mempunyai kepentingan pada organisasi itu, sesuai dengan aturan pokok dan tatacara yang ditentukan dan ditujukan untuk memberikan kepada penerima pelayanan.

Sistem informasi memiliki arti sekelompok elemen-elemen dalam suatu organisasi yang saling berintegrasi dengan menggunakan masukan, proses dan keluaran dengan maksud yang sama untuk mencapai suatu tujuan dan dapat digunakan untuk membantu pengambilan keputusan dengan tepat. Menurut James A Hall, sistem informasi adalah sebuah rangkaian prosedur formal dimana data dikumpulkan, diproses menjadi informasi dan didistribusikan kepada para pemakai (Hall, 2010: 6). berbeda dengan James A Hall, Jogiyanto berpendapat bahwa sistem informasi merupakan suatu sistem organisasi yang mempertemukan kebutuhan pengolahan transaksi harian, mendukung operasi organisasi, bersifat manajerial dan kegiatan strategi dari suatu organisasi dan menyediakan pihak luar tertentu dengan laporan-laporan yang diperlukan (Jogiyanto, 2005: 11).

Berbicara tentang sistem informasi desa sesungguhnya merupakan amanat Undang-Undang Nomor 6 Tahun 2014 tentang Desa, dimana mewajibkan pemerintah dan pemerintah daerah untuk mengembangkan 
sistem informasi desa yang terintegrasi beragam sistem informasi pemerintahan dengan memanfaatkan Teknologi Informasi dan Komunikasi (TIK) guna mendistribusikan informasi untuk meningkatkan pelayanan publik (Hidayat dan Noor, 2018: 1).

Pemanfaatan Teknologi Informasi dan Komunikasi (TIK) dalam pengelolaan sistem informasi desa pada pemerintahan desa dapat memberikan keuntungan diantaranya sebagai masukan dalam perencanaan pembangunan desa, mendukung pengambilan keputusan dan menjadi sarana pertanggungjawaban pemerintah desa dalam menyelenggarakan pemerintahan, sehingga dapat mewujudkan pemerintahan desa yang efektif dan efisien, transparan, akuntabel, mandiri serta mengurangi kesenjangan digital dan mampu mendorong peningkatan perekonomian masyarakat (Fitri, dkk, 2017: 100)

Berdasarkan Pasal 86 ayat (3) dan ayat (4) Undang-Undang Nomor 6 Tahun 2014 tentang Desa, sistem informasi desa dan pembangunan kawasan perdesaan yang dikembangkan pemerintah dan pemerintah kabupaten/kota meliputi fasilitas perangkat keras dan perangkat lunak, jaringan, serta sumber daya manusia, di samping data desa, data pembangunan desa, kawasan perdesaan, serta informasi lain yang berkaitan dengan pembangunan desa dan pembangunan kawasan perdesaan.

\section{Implementasi Pengembangan Model Pelayanan Publik Berbasis Sistem} Informasi Desa Pada Pemerintahan Desa Perspektif Islam Terapan

Implementasi (pelaksanaan) sistem informasi desa hakikatnya merupakan perwujudan pemerintah daerah kabupaten/Kota dalam mengamalkan amanat Undang-Undang Nomor 6 tahun 2014 tentang Desa, yaitu melakukan pengembangan sistem informasi desa dan pembangunan kawasan perdesaan guna menfasilitasi serta mendorong pemerintah desa untuk meningkatkan dan memberikan kemudahan dalam pelayanan publik, sehingga dapat diakses oleh masyarakat dan semua pemangku kepentingan. Penerapan Sistem Informasi Desa diharapkan dapat memberikan dampak positif dan sekaligus menjamin dalam penyelenggaraan pemerintahan desa agar lebih efektif dan efisien, transparan dan akuntabel. Kewajiban pengembangan sistem informasi desa tersebut melekat pada kabupaten/kota, bukan pada pemerintah pusat.

Pasal 86 ayat (4) Undang-Undang Nomor 6 Tahun 2014 tentang Desa, menegaskan bahwa Sistem Informasi Desa di antaranya meliputi data desa, data pembangunan desa, kawasan perdesaan, serta informasi lain yang berhubungan dengan pembangunan desa dan pembangunan kawasan perdesaan. Dari penjelasan Pasal tersebut dapat kita pahami bahwa sesunguhnya pemerintah desa berhak untuk mendapatkan akses 
Implementasi Pemerintah Daerah dalam Pengembangan...

informasi melalui sistem informasi desa yang dikembangkan oleh pemerintah daerah kabupaten/Kota. Sedangkan dalam pengelolaanya sistem informasi desa dikelola oleh pemerintah desa dan dapat diakses masyarakat dan semua pemangku kepentingan, oleh karenanya pemerintah daerah kabupaten/Kota dapat menyediakan informasi perencanaan pembangunan kabupaten/kota untuk Desa.

Dari hasil penelitian diketahui bahwa dasar hukum Implementasi (pelaksanaan) pengembangan pelayanan publik berbasis sistem informasi desa mengacu pada Undang-Undang Nomor 6 Tahun 2014 tentang Desa, Undang-Undang Nomor 25 Tahun 2009 tentang Pelayanan Publik, dan juga mengacu pada Peraturan Gubernur Provinsi Jawa Tengah Nomor 47 Tahun 2016 tentang Pedoman Pengembangan Sistem Informasi Desa di Provinsi Jawa Tengah (wawancara dengan Zulaekhah Almunawaroh, 21 Agustus 2019 ). Sementara itu, dalam pelaksanaanya dilakukan oleh Organisasi Perangkat Daerah yaitu Dinas Sosial Pemberdayaan Masyarakat dan Desa (Dinsospermades) Kabupaten Jepara bekerjasama dengan beberapa perangkat daerah lainnya seperti Dinas Kependudukan dan Catatan Sipil (Disdukcapil) Kabupaten Jepara, Dinas Komunikasi dan Informasi (Diskominfo) Kabupaten Jepara, dan Badan Pusat Statistik Kabupaten Jepara (imbuhnya).

Dalam rangka kelancaran pelaksanaan program pengembangan sistem informasi desa di Kabupaten Jepara, menurut Zulaekhah Almunawaroh, pihaknya menggandeng rekanan yaitu Badan Prakarsa Pemberdayaan Desa dan Kawasan (BP2DK) dari Jakarta dengan membuat aplikasi Sistem Informasi Desa dan Kawasan atau yang disebut SIDEKA. Pada dasarnya aplikasi SIDEKA isinya sama dengan profil desa hanya yang menjadi perbedaan di sini adalah SIDeKA terintegrasi dengan layanan publik dan kependudukan. Di Jawa Tengah, termasuk Kabupaten yang satu rekanan dengan BP2DK yaitu Kabupaten Demak dan Kabupaten Pati (Wawancara dengan Zulaekhah Almunawarah, Kasi Penguatan Perencanaan Pembangunan Partisipatif Dinsospermades Kabupaten Jepara, 7 Agustus 2019).

Harapannya dari pelaksanaan pengembangan sistem informasi desa yang terintegrasi dengan website desa ini, nantinya desa akan mampu memenuhi kebutuhan masyarakat desa dan semua pemangku kepentingan terutama di bidang pelayanan informasi dan data. Di samping itu, desa juga memiliki bargaining power jika sistem informasi desa tersebut dikelola dengan baik sesuai asas dan tujuan dalam UndangUndang Nomor 14 Tahun 2008 Tentang Keterbukaan Informasi Publik, dimana Pasal 2 menegaskan bahwa:

1) Setiap informasi publik bersifat terbuka dan dapat diakses oleh setiap pengguna informasi publik;

2) Informasi publik yang dikecualikan bersifat ketat dan terbaas; 
3) Setiap informasi publik harus dapat diperoleh setiap pemohon informasi publik dengan cepat dan tepat waktu, biaya ringan, dan cara sederhana;

4) Informasi publik yang dikecualika bersifat rahasia sesuai dengan Undang-Undang, kepatutan, dan kepentingan umum didasarkan pada pengujian tentang konsekuensi yang timbul apabila suatu informasi diberikan kepada masyarakat serta setelah dipertimbangkan dengan seksama bahwa menutup informasi publik dapat melindungi kepentingan yang lebih besar daripada membukanya atau sebaliknya.

Ketentuan pasal di atas, dapat dipahami bahwa memperoleh informasi merupakan hak asasi manusia, dan keterbukaan informasi merupakan salah satu ciri dalam negara berbasis demokrasi yang menjunjung tinggi kedaulatan rakyat sebagai upaya dalam mewujudkan penyelenggaraan pemerintah dengan mendasarkan pada prinsip-prinsip good governance. Pasal 1 ayat (1) Undang-Undang Nomor 14 Tahun 2008 tentang Keterbukaan Informasi Publik, mengatakan bahwa yang dimaksud informasi yaitu keterangan, penryataan, gagasan, dan tandatanda yang mengandung nilai, makna, dan pesan, baik data, fakta maupun penjelasannya yang dapat dilihat, didengar, dan dibaca yang disajikan dalam berbagai kemasan dan format sesuai dengan perkembangan teknologi informasi dan komunikasi secara elektronik dan non elektronik.

Kembali pada pokok permasalahan di atas, bahwa bentuk pelaksanaan pengembangan pelayanan publik berbasis sistem informasi desa yang dilakukan oleh Dinsospermades Kabupaten Jepara yaitu melalui beberapa program kegiatan diantaranya (Wawancara dengan Bambang Selamet Raharjo, Kepala Dinsospermades Kabupaten Jepara, 7 Agustus 2019):

Pertama, sosialisasi sistem informasi desa dan mengenalkan integrasi program aplikasi sistem informasi lainnya. Sasaran dari kegiatan sosialisasi ini adalah semua operator desa/kepala desa di Kabupaten Jepara. Perlu diketahui bahwa operator desa merupakan ujung tombak keberhasilan terhadap pengelolaan sistem informasi desa di masingmasing desa. Kegiatan sosialisasi ini bertujuan mengenalkan kepada operator desa terkait aplikasi apa saja yang terintegrasi dengan program SIDEKA sehingga harapannya ke depan operator desa dapat membantu tugas-tugas dari pemerintah desa utamanya memberikan pelayanan administrasi yang berbasis daring. Kedua, memberikan pelatihan dan bimbingan teknis kepada operator desa. Tujuan dari pelatihan dan bimbingan teknis ini untuk membekali pengetahuan kepada operator desa terkait mekanisme pengelolaan, dengan begitu operator desa mengerti dan terampil dalam mengelola sistem informasi desa yang terintegrasi 
Implementasi Pemerintah Daerah dalam Pengembangan...

dengan website desa. Secara teknis pelaksanaan pelatihan dan bimbingan teknis dilakukan berdasarkan zona kewilayahan kecamatan.

Dari hasil penelitian menujukkan bahwa kegiatan pelatihan dan bimbingan teknis yang diselenggarakan oleh Dinsospermades Kabupaten Jepara memiliki kemanfaatan seperti yang dikatakan Kepala Desa Krapyak, bahwa dengan adanya pelatihan dan bimbingan teknis membuka pengetahuan khususnya bagi operator desa sehingga mereka terampil dalam mengelola dengan baik sistem informasi desa yang terintegrasi dengan website desa krapyak, dan alhamdulillah desa krapyak menjadi desa percontohan bagi desa-desa lain dalam hal manajemen pengelolaan (Wawancara dengan Munawir, Kepala Desa Krapyak, 19 Agustus 2019).

Dalam kesempatan lain terkait program pelatihan dan bimbingan teknis, Kepala Desa Kedungcino mengatakan bahwa pihaknya sangat senang dan mengapresiasi Dinsospermades Kabupaten Jepara yang telah memberikan pencerahan kepada operator desa sehingga mereka mampu mengelola website desa dengan baik, dan hal tersebut berimplikasi positif bagi desa yaiu masyarakat semakin percaya terhadap Pemerintah Desa Kedungcino karena setiap kegiatan desa atau yang berkaitan dengan pembangunan desa diungah di website desa (Wawancara dengan Rahmad, Kepala Desa Kedungcino, 15 Agustus 2019). Hal senada juga disampaikan Operator Desa Krapyak, mengatakan bahwa program pelatihan dan bimbingan teknis tidak hanya memberikan manfaat pengetahuan tentang bagaimana tata cara mengelola sistem informasi desa, tetapi juga menambah relasi (Wawancara dengan Wahidul Huda, Operator Desa, 19 Agustus 2019).

Ketiga, melakukan monitoring dan evaluasi. Monitoring dilakukan bertujuan untuk memantau perkembangan sistem informasi desa yang dijalankan oleh operator desa, sedangkan Kegiatan evaluasi dilakukan oleh Dinsospermades Kabupaten Jepara guna mengetahui sejauhmana telah melaksanakan tugas dan fungsinya dalam mengelola aplikasi sistem informmasi desa, dengan evaluasi, maka akan diketahui kelebihan dan kekurangan dari masing-masing opertor desa tersebut.

Menurut Zulaekhah Almunawaroh, dari pemantauan dan evaluasi yang dilakukan menunjukkan bahwa operator desa yang aktif dalam pengisian sistem informasi desa adalah operator desa di wilayah Kecamatan Tahunan, Kecamatan Jepara, Kecamatan Mlonggo, dan Kecamatan Karimunjawa. Kemudian sebagian besar desa yang belum optimalnya pengelolaan sistem informasi desa di Kabupaten Jepara, hal tersebut dikarenakan lemahnya kualitas sumber daya manusia operator desa, di samping kurangnya komitmen dari pemerintah desa.

Serangkaian bentuk program yang dilakukan oleh Pemerintah Daerah melalui Dinsospermades Kabupaten Jepara, menurut hemat 
penulis, bahwa Pemerintah Daerah telah melaksanakan kewajibannya dalam mengamalkan Pasal 86 Undang-Undang Nomor 6 Tahun 2014 tentang Desa, yakni mengembangkan sistem informasi desa yang bertujuan untuk peningkatan pelayanan kepada masyarakat dan semua pemangku kepentingan terutama berkaitan dengan informasi dan data desa, di samping pemerintah daerah telah menjalankan fungsi pemerintahan dan fungsi pembinaan berdasarkan Undang-Undang Nomor 23 Tahun 2014 Juncto Undang-Undang Nomor 9 Tahun 2015 tentang Pemerintahan Daerah. Tugas dan fungsi yang telah dijalankan tersebut dimaknai telah sejalan dengan konsep Islam Terapan, artinya Pemerintah Daerah tidak hanya memahami norma dasar sebagai pijakan dalam tata kelola pemerintahan saja tetapi juga mengimplementasikan norma dasar tersebut pada ranah praktis guna mewujudkan penyelenggaraan pemerintahan di tingkat desa yang efektif dan efesien, transparan, dan akuntabel. Tentu saja hal tersebut secara substansial mengandung unsur kemaslahatan sebagaimana yang dikendaki dalam ajaran Islam (maqasid syariah).

Terhadap permasalahan kurangnya komitmen dari pemerintah Desa dalam hal ini Kepala Desa atau dengan sebutan lainnya, maka dalam konsepsi Islam Terapan sikap tersebut dinilai tidak mencerminkan penerapan sikap keberagamaan orang beriman dalam mewujudkkan kemaslahatan masyarakat dan menerapkan prinsip-prinsip good governance dalam rangka pengembangan kualitas pelayanan publik. Tanggung jawab adalah bagian dari ajaran Islam yang disebut ma'uliyyah. Untuk itu, sebagai penyelenggara pemerintahan sudah seharusnya mengamalkan ajaran agama (keberagamaan) agar tercipta pemerintahan yang baik, dimana nilai-nilai good governance telah menjadi bagian yang diperintahkan dalam ajaran Islam untuk melaksanakannya.

Dalam kajian penelitian sebelumnya sebagaimana ditulis Sri Warjiyati dengan judul "Tinjauan Hukum Islam Terhadap Penerapan Good Governance Dalam Pelayanan Publik" mengatakan bahwa untuk mewujudkan pemerintahan yang baik, maka harus mengacu pada penerapan konsep maslahat dalam sistem pemerintahan. Hal ini mengingat konsep maslahat sangat sesuai dengan kondisi dan tempat demi mewujudkan suatu kemaslahatan dalam pemerintahan, dengan begitu apa yang dicita-citakan terwujudkan pemerintahan yang baik akan benar-benar teralisasi sebab semua kebijakan yang diambil oleh penyelenggara pemerintahan (pemerintah) untuk kebaikan masyarakat yang dipimpinya (Warjiyati, 2018: 130-131). Sejalan dengan Sri Warjiyati, Nur Rohim Yunus dalam penelitiannya yang berjudul "Menciptakan Good and Clean Goverment Berbasis Syariah Islamiyah Dalam Tata Kelola Pemerintahan Republik Indonesia" mengatakan bahwa good governance hakikatnya merupakan hasil pemikiran manusia yang bertujuan untuk 
Implementasi Pemerintah Daerah dalam Pengembangan...

mencapai maslahat dan menjadi tujuan hukum Islam (maqasid syariah). Adapun maslahat sebagaimana yang dimaksud adalah terwujudnya penyelenggaraan pemerintahan yang transparan dan penuh tanggung jawab dengan mendasarkan pada prinsip demokratis, pencegahan korupsi baik secara administratif maupun politik dan merealisasikan hukum maupun kerangka kerja politik bagi tumbuhnya kegiatan usaha masyarakat (Yunus, 2016: 170)

Pada dasarnya Islam telah mengajarkan bagaimana pemerintahan seharusnya dijalankan untuk menciptakan good governance, meskipun di dalam Al-Qur'an tidak dijelaskan secara eksplisit bahasan terkait good governance pada pemerintahan, namun Al-Qur'an secara garis besar menjelaskan tentang bagaimana konsep akuntabiltas, transparansi, keadilan dan keseimbangan. Dalam kajian Fikih, persoalan good governance merupakan bagian dari Fikih Siyasah dimana penetapan hukumnya mengacu kemaslahatan dan kepentingan masyarakat. Titik temu antara Fikih Siyasah dan good governance terletak pada pengendalian, sistem pengaturan, dan pelaksanaan dalam suatu wilayah atau negara.

Sehubungan dengan hal tersebut, maka dapat dikatakan bahwa good governance sejalan dengan konsep maqasid syariah karena pada prinsipnya good governance mempunyai tujuan yang sama dengan maqasid syariah (Muhammadong, 2017: 3). Oleh karena itu, semua aktivitas pemerintah dalam rangka penyelenggaraan pemerintahan harus sejalan dengan ajaran Islam yaitu Al-Qur'an dan Hadis sebagai wujud pengamalan keberagamaan, karena setiap perbuatan nantinya akan dipertanggungjawabkan dihadapan Allah SWT sebagaimana dijelaskan dalam Surat An-Nisa ayat (58) yang berbunyi:

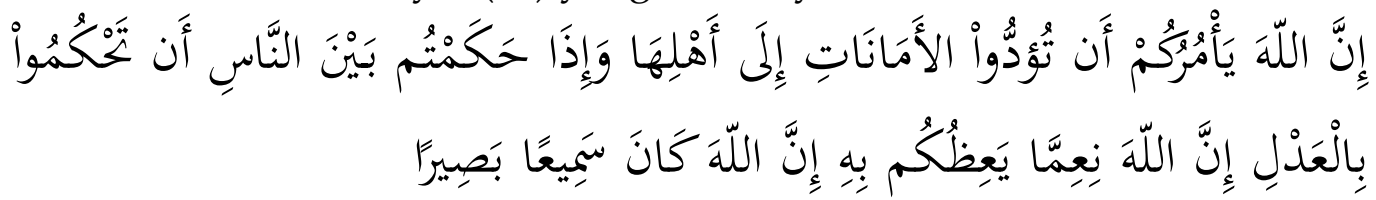

Artinya : "Sesungguhnya Allah menyuruh kamu menyampaikan amanat kepada yang berhak menerimanya, dan menyuruh kamu apabila dalam menetapkan hukum di antara mereka supaya kamu menetapkan dengan adil. Sesunggunya Allah memberi pengajaran yang sebaikbaiknya kepadamu. Sesungguhnya Allah adalah Maha Mendengar Lagi Maha Melihat" (Tim Pelaksana, Al-Qur'an dan Terjemah Bahasa Indonesia, $1427 \mathrm{H}: 87)$.

Surat Al-Muddassir ayat (38) yang berbunyi:

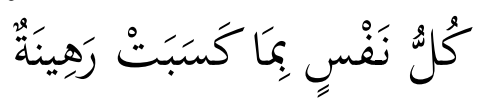

Artinya : "Tiap-tiap diri bertanggungjawab atas apa yang telah diperbuatnya"

(Tim Pelaksana, Al-Qur'an dan Terjemah Bahasa Indonesia, 1427 H: 576). 
Rasulullah SAW dalam hadis yang diriwayatkan oleh al- Bukhari yaitu:

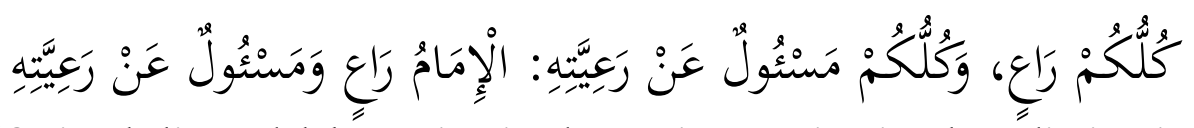

Artinya : "Setiap kalian adalah pemimpin dan setiap pemimpin akan dimintai pertanggung jawaban atas yang dipimpinya. Imam adalah pemimpin yang akan dimintai pertanggung jawaban atas rakyatnya" (Sunarta dan Noor, 2009: 103).

Dari ayat Al-Qur'an dan Hadis di atas, mengingatkan kepada setiap manusia agar lebih berhati-hati dalam menjalankan kepemimpinannya karena semua itu akan dimintai pertanggungjawaban dihadapan Allah SWT. Dalam kaitannya good governance, komitmen seorang pemimpin dan juga pemegang amanah di pemerintahan akan sangat berimplikasi pada proses reformasi birokrasi dalam menuju good governance. Untuk itu, dibutuhkan sikap keteguhan keberagamaan sebagai perwujudan dalam menjalankan ajaran agama. keberagamaan dalam kajian Islam Terapan mengandung pengertian yakni cara pandang seseorang dalam merespon ajaran agama yang diimplementsikan dalam kehidupan sehari-hari baik dalam tataran kehidupan keluarga, masyarakat, berbangsa dan bernegara (Kadir, 2003: 5).

\section{Kendala dan Upaya yang Dapat Dilakukan Pemerintah Daerah Kabupaten Jepara dalam Pengembangan Model Pelayanan Publik Berbasis Sistem Informasi Desa Pada Pemerintahan Desa}

Kewenangan Pemerintah Daerah dalam pengembangan sistem informasi desa sebagaimana tertuang dalam Pasal 86 Undang-Undang Nomor 6 Tahun 2014 tentang Desa pada prinsipnya adalah untuk meningkatkan kemandirian Desa. Prakarsa sistem informasi desa sesungguhnya dapat berasal dari prakarsa masyarkat desa dimana dalam pelaksanaannya tetap dikelola oleh Pemerintah Desa, sebab UndangUndang tentang Desa tidak secara spesifik menyebutkan sistem informasi desa sebagai suatu sistem yang dikeluarkan oleh institusi yang ditunjuk oleh pemerintah pusat. Dengan demikian, sistem informasi desa merupakan kewenangan Pemerintah Daerah dalam menerapkan sistem informasi desa yang disesuaikan dengan kebutuhan masyarakat dan pembangunan nasional ditingkat desa.

Pada tataran pelaksanaannya, sistem informasi desa sebagai upaya pengembangan pelayanan publik pada pemerintahan desa tidaklah mudah, terdapat beberapa kendala yang harus dihadapi. Menurut Zulaekha Almunawaroh, beberapa kendala yang dihadapi diantaranya (Wawancara dengan Zulaekha Almunawaroh, Tanggal 7 Agustus 2019):

Pertama, sumber daya manusia operator desa masih rendah. Tidak dipungkiri bahwa sebagaian besar operator desa di Kabupaten Jepara 
Implementasi Pemerintah Daerah dalam Pengembangan...

sebagai pengelola sistem informasi desa yang terintegrasi dengan website desa rata-rata berpendidikan Sekolah Menengah Atas (SMA) ditambah dengan pembiasaan pemanfaatan teknologi yang masih minimum, sehingga dari mereka tidak bisa beradaptasi dengan aplikasi sistem informasi desa meskipun pelatihan dan bimbingan teknis sudah diberikan. Kedua, belum adanya regulasi petunjuk tekni atau Standar Operasional Prosedur (SOP) untuk pengelolaan Sistem Informasi Desa. Pengelolaan aplikasi sistem informasi desa yang terintegrasi website desa selama ini hanya sesuai dengan arahan dari Dinas Dinsospermades terkait, sehingga operator dalam menjalankannya terkadang mengalami kendala tersendiri.

Ketiga, kurangnya komitmen dari kepala desa. Kenyataan belum optimalnya pengelolaan sistem infomasi desa hampir sebagian besar desa di Kabupaten Jepara disebabkan kurangnya tingkat kepedulian kepala desa dan bahkan dari penulusuran terdapat beberapa kepala desa yang tidak mengerti apa dan bagaimana tentang sistem informasi desa dan dasar hukum dalam pengelolaan sistem informasi desa. Keempat, operator desa yang sering berganti-ganti disebabkan tidak adanya operator khusus. Dengan berganti-ganti operator dan tidaknya operator khusus dalam pengelolaan sistem informasi desa, maka dapat berpengaruh terhadap ketidakefektifan dalam pelaksanaan pengembangan sistem informasi desa. Kelima, keterbatasan anggaran dalam pengembangan Sistem Informasi Desa. Disadari atau tidak anggaran memainkan peran yang sangat penting utamanya dalam peningkatan kualitas pengembangan sistem informasi desa terlebih peningkatan kapasitas pengelolanya.

Berdasarkan kendala-kendala yang dihadapi di atas, maka upaya yang dapat dilakukan Pemerintah Daerah Kabupaten Jepara melalui Dinsospermades Kabupaten Jepara yaitu pertama, terkait sumber daya manusia operator desa masih rendah, maka Pemerintah Daerah Kabupaten Jepara melalui Dinsospermades Kabupaten Jepara dapat memberikan pendampingan secara intensif melalui forum diskusi secara berkala tiap bulan tujuannya untuk sharing seputar permasalahan pengelolaan sistem informasi desa. Forum diskusi juga dapat dilakukan dalam bentuk daring yaitu whatsapp group dan lain sebaginya, hal ini penting untuk dilakukan mengngat operator desa merupakan ujung tombak keberhasilan dalam pengelolaan informasi dan data desa.

Kedua, belum adanya Standar Operasional Prosedur (SOP) maupun regulasi terkait pengelolaan sistem informasi desa, maka melalui dinas terkait segera mendesak kepada pemangku kebijakan (Kepala Daerah) untuk menerbitkan SOP maupun menerbitkan regulasi berupa Peraturan Bupati atau Keputusan Bupati sebagai acuan dalam pengembangan dan pengelolaan sistem informasi desa di Kabupaten 
Jepara. Dengan adanya regulasi dan Standar Operasional Prosedur (SOP) tersebut, maka pengelolaan sistem informasi desa akan lebih terarah sehingga efektivitas dapat dicapai sesuai tujuan yang diharapkan. Pendapat ini, sejalan dengan Desi Fernanda dalam artikelnya yang berjudul "Pengembangan Pelayanan Publik di Daerah" mengatakan bahwa beberapa upaya yang dapat dilakukan oleh pemerintah daerah dalam penyelenggaraan pelayanan publik diantaranya : 1) pengaturan dan penetapan kebijakan berupa perda dan keputusan kepala daerah; 2) penyediaan barang dan jasa publik secara langsung oleh pemerintah daerah; 3) pemberian kemudahan berupa bantuan atau subsidi kepada masyarakat; 4) pelayanan administrasi seperti sertifikasi dan perijinan; 5) pemberian layanan publik secara tidak langsung melalui pihak ketiga (Fernanda, 2003: 177)

Ketiga, kurangnya komitmen dan dukungan dari kepala desa, maka Dinsospermades Kabupaten Jepara dapat melakukan pembinaan secara intensif kepada kepala desa atau sebutan lainnya sehingga mereka memiliki kesadaran untuk berpartisipasi dalam pelaksanaan pengembangan sistem informasi desa sebagai bentuk mendukung program dari Pemerintah Daerah Kabupaten Jepara. Jika diperlukan diberikan sanksi yang tegas misalnya berupa penundaan dalam pencairan dana desa. Ketegasan sanksi diberikan sebagai bentuk peringatan bagi kepala desa untuk lebih adaptif berorientasi pada pelayanan prima di era digital sekrang ini sebagaimana yang diamanatkan Undang-Undang Nomor 6 Tahun 2014 tentang Desa, yakni hubungannya dalam tugas dan Kewajiban Pemerintah Desa dalam menyelenggarakan pemerintahan desa.

Keempat, operator desa yang sering berganti-ganti disebabkan tidak adanya operator khusus, dinas terkait dapat merekomendasikan kepada kepala desa untuk mengangkat dan menetapkan seseorang menjadi operator yang bertugas untuk mengelola sistem informasi desa secara berkelanjutan, harapannya dengan keajekan operator desa dalam mengelola aplikasi tersebut akan lebih mudah menselaraskan pengelolaan sehingga tujuan dari pengembangan sistem informasi desa dapat terealisasi dengan baik. Kelima, keterbatasan anggaran dalam pengembangan sistem informasi desa, langkah yang dapat dilakukan Dinsospermades Kabupaten Jepara yakni mengusulkan penambahan alokasi anggaran kepada pemangku kebijakan yang berwenang guna mendukung penyediaan sarana dan prasarana maupun untuk peningkatan kapasitas operator melalui kegiatan seminar, workshop dan lain sebagainya. 
Implementasi Pemerintah Daerah dalam Pengembangan...

\section{SIMPULAN}

Realitas pengembangan pelayanan publik berbasis sistem informasi desa dewasa ini, menjadi kewajiban bagi pemerintah daerah untuk memberikan akses informasi kepada desa. Adanya sistem informasi desa yang dikembangkan Pemerintah Daerah Kabupaten Jepara dan dikelola oleh pemerintah desa ini sebagai upaya memberikan kemudahan pelayanan informasi dan data kepada masyarakat desa maupun semua pemangku kepentingan secara cepat dan tepat sekaligus menjadikan desa sebagai lumbung data. Dasar hukum pelaksanaan pengembangan pelayanan publik berbasis sistem informasi desa mengacu pada UndangUndang Nomor 6 Tahun 2014 tentang Desa, Undang-Undang Nomor 25 Tahun 2009 tentang Pelayanan Publik, Undang-Undang Nomor 14 Tahun 2008 tentang Keterbukaan Informasi Publik, dan Peraturan Gubernur Provinsi Jawa Tengah Nomor 47 Tahun 2016 tentang Pedoman Pengembangan Sistem Informasi Desa di Provinsi Jawa Tengah.

Pengembangan pelayanan publik berbasis sistem informasi desa

yang dilakukan pemerintah Daerah Kabupaten Jepara melalui Dinsospermades Kabupaten Jepara sudah sejalan dengan konsep Islam Terapan, artinya Pemeritah Daerah Kabupaten Jepara sebagai institusi telah melaksanakan kewajibannya dengan mengamalkan Pasal 86 Undang-Undang Nomor 6 Tahun 2014 tentang Desa demi mewujudkan kemaslahatan masyarakat terkait kemudahan akses pelayanan informasi dan data desa. Titik temu antara konsep Islam Terapan dengan UndangUndang tetang Desa adalah sama-sama bertujuan untuk kemaslahatan atau kesejahteraan masyarakat. Bentuk pelaksanaannya meliputi sosialisasi sistem informasi desa dan mengenalkan integrasi program aplikasi sistem informasi lainnya, memberikan pelatihan dan bimbingan teknis kepada operator desa, melakukan monitoring dan evaluasi.

Pada tataran pelaksanaannya, pengelolaan sistem informasi desa di tingkat desa terdapat beberapa kendala diantaranya sumber daya manusia operator desa masih rendah, belum adanya peraturan pelaksana dan peraturan teknis atau Standar Operasional Prosedur (SOP) dari Pemerintah Kabupaten Jepara, kurangnya komitmen dari Kepala Desa, pengelola (operator desa) yang cenderung berganti-ganti, dan keterbatasan anggaran. Untuk itu, upaya yang dapat dilakukan dalam mengatasi kendala tersebut diantaranya Dinsospermades memberikan pendampingan intensif melalui forum diskusi secara berkala tiap bulan, mendesak kepada pihak pemangku kebijakan (kepala daerah) untuk segera menerbitkan Peraturan Bupati atau Keputusan Bupati, melakukan pembinaan kepada kepala desa sehingga mereka memiliki kesadaran dan tanggung jawab dalam pengelolaan sistem informasi desa sehingga masyarakat dan semua pemangku kepentingan akan mudah dalam mengakses layanan informasi dan data desa, merekomendasikan kepada 
kepala desa untuk mengangkat dan menetapkan seseorang menjadi operator desa, Pemerintah Daerah Kabupaten Jepara mengusulkan untuk menambah alokasi anggaran untuk penyelenggaraan pengembangan sistem informasi desa guna mendukung penyediaan sarana dan prasarana maupun untuk peningkatan kapasitas operator desa melalui kegiatan seminar, workshop dan lain sebagainya.

\section{DAFTAR PUSTAKA}

\section{Buku-buku}

H.M. Jogiyanto. Analisa dan Desain Sistem Informasi: Pendekatan Terstruktur Teori Dan Praktik Aplikasi Bisnis. Yogyakarta: Andi Offset, 2005.

Harsono, Hanifah. Implementasi Kebijakan dan Politik. Bandung: Mutiara Sumber Widya, 2002.

Hall, James A. Sistem Informasi Akuntansi, Edisi 4, Terjemahan Dewi Fitriani. Jakarta: Salemba Empat, 2010.

Kadir, Muslim A. Ilmu Islam Terapan, Menggagas Paradigma Amali Dalam Agama Islam. Yogyakarta: Pustaka Pelajar, 2003.

Lembaga Administrasi Negara Republik Indonesia. Pelayanan Publik: Modul Pelatihan Dasar Kader PNS, Edisi Revisi. Jakarta: LAN RI, 2016.

Mardiasmo, Otonomi dan Manajemen Keuangan Daerah. Yogyakarta: Andi Offset, 2002.

Mardikanto, Totok dkk. Pemberdayaan Masyarakat Dalam Perspektif Kebijakan Publik. Bandung; Alfabeta, 2012.

Munir. Manajemen Pelayanan Umum. Jakarta: Bumi Aksara, 2006.

Miftah, Thoha. Perilaku Organisasi: Konsep Dasar dan Aplikasinya. Jakarta: Rajagrafindo Persada, 1996.

Muhammadong. Good Governance Dalam Perspektif Hukum Islam. Makasar: Edukasi Mitra Grafika, 2017.

Sugiyono. Metode Penelitian Pendidikan: Pendekatan Kuantitati, Kualitatif, $R$ $\mathcal{E}$ D. Bandung: Alfabeta, 2010.

Sunarta, Ahmad dan Noor Syamsuddin. Himpunan Hadis Shahih Bukhari. Jakarta: An-Nur, 2009.

Tim Pelaksana. Al-Qur'an dan Terjemah Bahasa Indonesia. Kudus: Menara Kudus, $1427 \mathrm{H}$.

\section{Jurnal-Jurnal}

Fitri, Rahmi, dkk. Pengembangan Sistem Informasi Desa Untuk Menuju Tata Kelola Desa Yang Baik (Good Governance) Berbasis TIK. Jurnal Positif, Volume 3, No. 2, 2017. 
Implementasi Pemerintah Daerah dalam Pengembangan...

Fernanda, Desi. Pengembangan Kualitas Pelayanan Publik di Daerah. Jurnal Administrasi Publik, Volume 2. No. 2, Oktober 2003.

Hidayat, Syarif dan Noor Sowandi. Pengembangan Sistem Informasi Desa Terintegrasi. Jurnal Global, Volume IV. No 2/Juli/2018.

Kurniawan, Robi Cahyadi. Tantangan Kualitas Pelayanan Publik Pada Pemerintah Daerah. Jurnal Ilmiah Administrasi Publik dan Pembangunan, Vol. 7 No. 1 Januari-Juni 2016.

_ Inovasi Kualitas Pelayanan Publik Pemerintah Daerah. Fiat Justisia Vol. 10 No. 3, Juli-September 2016

Nazli, Rabby. Pemodelan Aplikasi Mobile Pelayanan Publik Desa (Smart Village) Berbasis Cloud Computing. Jurnal Teknologi dan Open Source, Vol. 2, No. 2, Desember 2019.

Samudra, Putra, dkk,. Sistem Administrasi Pelayanan Pemeritah Desa Berbasis Website Studi Kasus Kantor Balai Desa Kendalkemilagi Kecamatan Karanggeneng Kebupaten Lamongan. Jurnal Fakultas Teknik Program Studi Teknik Informatika, ISSN: 2503-07103, Universitas Islam Lamongan.

Warjiyati, Sri. Tinjauan Hukum Islam Terhadap Penerapan Good Governance Dalam Pelayanan Publik. Jurnal Hukum Islam, Vol. XVIII, No. 1 Juni 2018.

Yunus, Nur Rohim. Menciptakan Good and Clean Goverment Berbasis Syariah Islamiyah Dalam Tata Kelola Pemerintahan Republik Indonesia. Jurnal Nur El-Salim, Volume 3 Nomor 1, April 2016.

\section{Peraturan Perundang-Undangan}

Undang-Undang Nomor 23 Tahun 2014 Juncto Undang-Undang Nomor 9

Tahun 2015 tentang Pemerintahan Daerah

Undang-Undang Nomor 6 Tahun 2014 tentang Desa

Undang-Undang Nomor 25 Tahun 2009 tentang Pelayanan Publik

Undang-Undang Nomor 14 Tahun 2008 Tentang Keterbukaan Informasi Pulik

Peraturan Menteri Dalam Negeri Nomor 12 Tahun 2007 tentang Pedoman Penyusunan dan Pendayagunaan Data Profil Desa dan Kelurahan

Keputusan Menteri Pendayagunaan Aparatur Negara Nomor Kep/26/M.PAN/2/2004 tentang Pedoman Umum Pelayanan Publik

Peraturan Gubernur Provinsi Jawa Tengah Nomor 47 Tahun 2016 tentang Pedoman Pengembangan Sistem Informasi Desa di Provinsi Jawa Tengah. 
Aristoni

Halaman ini sengaja dikosongkan 